\title{
Article \\ Collaborative Production Task Decomposition and Allocation among Multiple Manufacturing Enterprises in a Big Data Environment
}

\author{
Feng $\mathrm{Li}^{1}$, Xiya $\mathrm{Li}^{1}{ }^{1} * \mathbb{D}$, Yun Yang ${ }^{2}$, Yan $\mathrm{Xu}^{2}$ and Yan Zhang ${ }^{1}$ \\ 1 School of Informatics, Beijing Wuzi University, Beijing 101149, China; lifeng@bwu.edu.cn (F.L.); \\ zhangyan6@bwu.edu.cn (Y.Z.) \\ 2 School of Economics and Management, Xidian University, Xi'an 710126, China; \\ yyang_1011@stu.xidian.edu.cn (Y.Y.); yxu_4@stu.xidian.edu.cn (Y.X.) \\ * Correspondence: sialee310@gmail.com
}

check for updates

Citation: Li, F.; Li, X.; Yang, Y.; Xu, Y.; Zhang, Y. Collaborative Production Task Decomposition and Allocation among Multiple Manufacturing Enterprises in a Big Data Environment. Symmetry 2021, 13, 2268. https://doi.org/10.3390/ sym 13122268

Academic Editors: Deming Lei and Ming Li

Received: 29 October 2021 Accepted: 18 November 2021 Published: 28 November 2021

Publisher's Note: MDPI stays neutral with regard to jurisdictional claims in published maps and institutional affiliations.

Copyright: (c) 2021 by the authors. Licensee MDPI, Basel, Switzerland. This article is an open access article distributed under the terms and conditions of the Creative Commons Attribution (CC BY) license (https:// creativecommons.org/licenses/by/ $4.0 /)$.

\begin{abstract}
To realize the efficient decomposition and allocation of collaborative production tasks and resources among multiple enterprises, a task decomposition and allocation model for collaborative production among multiple manufacturing enterprises is proposed in a big data environment. The model is designed for the efficient and fast processing of production information using big data technology. This study innovatively applies the $5 \mathrm{~S}$ management method to conduct data preprocessing for a manufacturing service provider and design the operation process of data cleaning and conversion to improve the efficiency of data processing. A collaborative optimization model, based on a hierarchical model with seven levels and considering time, costs, and services, is established for the task of production to achieve a reasonable match between supply and demand. Finally, the correlation coefficients of manufacturing service providers are configured according to weight order, so that the weight order is symmetrical with that of the manufacturer. The model also engages all manufacturing service providers with different production capabilities in collaborative production. The model is proved to be scientific and effective by using a specific example. In cooperative production activities, the production tasks of small and medium-sized enterprises can be effectively allocated. It can also realize efficient cooperative production among multiple manufacturing enterprises.
\end{abstract}

Keywords: 5S management; big data; collaborative production; task allocation; genetic algorithm

\section{Introduction}

Currently, the strategic planning of schemes such as Industry 4.0 [1], Industrial Internet [2], and Made in China 2025 [3] creates opportunities for the digitalization of the manufacturing industry, solves the problem of information symmetry in the coordinated production of multiple enterprises, and presents advanced requirements for its development. The "one-stop" production model of traditional enterprises is no longer competitive, and the collaborative production model has become the "new favorite" of the manufacturing industry. In the collaborative production model, the decomposition and allocation of production tasks have become urgent issues for production and supplier services.

Task allocation is a key factor in the improvement of efficiency and reliability in the manufacturing system [4]. Scholars, both in China and overseas, have carried out relevant studies from various perspectives. Ebadifard [5] and Zhao et al. [6] studied the allocation of resources and tasks in specific situations. Liu et al. [7] and Zhou et al. [8] used public service platforms and crowdsourcing platforms as research objects, respectively, and discussed issues of production task allocation. Shahrabi et al. [9] and Erişgin et al. [10] studied the same dynamic job-shop scheduling on parallel machines, using fuzzy order parameter estimation with a receiving and dispatching optimal learning method.

In the process of studying task allocation, scholars often improve existing algorithms based on actual conditions, to find ways to improve workshop efficiency. For instance, 
Zhou et al. [11] studied the problem of the remote distributed collaborative development of complex products in a dynamic environment; in addition, they established a task allocation model of remote distributed multi-team collaborative development, based on an unconstrained coding method and a hybrid leapfrog algorithm. Chaouch et al. [12] proposed a hybrid ant colony algorithm combined with a local search to solve the distributed job shop scheduling problem. Kurdi et al. [13] used the new island-model genetic algorithm in the study of task assignment models. Nouri et al. [14] used a hybrid meta-heuristic algorithm to study the scheduling problem of machines and transportation robots regarding the task allocation problem. Salido et al. [15] used genetic algorithms to study energy efficiency issues in task allocation. Agárdi et al. [16] proposed a hybrid discrete bacterial memetic algorithm with simulated annealing, which is a major improvement in the research field of memetic algorithms.

The abovementioned scholars also focused on task allocation within a single enterprise or platform and have attained remarkable achievements, based on which, some scholars have tried to explore the allocation of cross-platform collaborative production tasks. For example, Zhou et al. [17] studied the decision-making of optimal product output when supply-chain members have different bargaining powers, regarding the collaborative production problem in the secondary supply chain, including upstream manufacturers and downstream treatment plants. Wang et al. [18] studied the complex collaborative production problem across various enterprises in a cloud-based manufacturing environment and proposed a hybrid set planning method to solve the scheduling problem of production resources. The above studies have achieved resource optimization among enterprises. However, there have been few studies on task decomposition and assignment integration among enterprises.

The application and promotion of 5G technology, cloud computing, the Internet of Things, and other novel technologies have accumulated a large amount of structured and unstructured data in the manufacturing industry worldwide. With the rapid expansion of the scale of the manufacturing industry and of the supply chain with its synergistic relationship, the contradiction between the production of massive amounts of data in the manufacturing industry and the lack of corresponding data-processing mechanisms is extremely prominent. Some scholars have conducted useful explorations of this problem. Meng et al. [19] solved the problem of traditional data center loads only pursuing resource utilization maximization by innovatively introducing a time utility function in the model construction and proposing an online heuristic dynamic resource allocation algorithm for data centers. Ren et al. [20] studied the information and knowledge interactions between subtasks in complex task scenarios. They proposed a mathematical model for the hybrid multi-objective task allocation optimization of the network. This was performed through the dynamic matching of task networks and service collaboration networks, comprehensively considering the competence and collaboration level of service groups. Zheng et al. [21] considered problems such as information interaction and distortion in collaborative production situations and proposed a task allocation method for multisupplier collaborative production, based on big data. Wang et al. [22] proposed a task allocation algorithm for big data computing based on accurate user perception by using adaptive fuzzy clustering, topic extraction model, logistic regression, and other methods to solve the inefficient problem of the traditional random task allocation algorithm. Currently, relevant achievements focus on manufacturing-related data from various perspectives, such as information interaction granularity, interaction efficiency, and knowledge extraction. As the front-end input of the manufacturing task decomposition and distribution stage, the processing mechanisms of various techniques, such as rapid data acquisition, efficient data conversion, and accurate data analysis, need further study. Therefore, the 5 s management method of data processing from the source can offer a good solution to issues with the efficiency of front-end input.

Studies have proved that having sufficient data mining and analysis is immensely beneficial to enterprises. The big data processing mechanism can improve the market 
competitiveness of the manufacturing industry by mining the hidden knowledge value and potential capabilities of industrial big data, assisting business leaders to form scientific and accurate decisions in various complex manufacturing environments [19]. Therefore, based on the characteristics of task decomposition and allocation for collaborative production, and the advantages of big data in data collection, processing, and analysis, the task allocation framework on the Hadoop platform is designed to build the task allocation model of multi-manufacturing enterprises to achieve cross-enterprise collaborative production in the shortest time and with the lowest cost.

Therefore, the contribution of this paper lies in the innovation and integration of 5S management methods, giving full play to the advantages of data mining in information interaction granularity, interaction efficiency and knowledge extraction. The efficiency of data acquisition and data conversion is improved effectively. This will contribute to the structural adjustment of traditional manufacturing industry and the rational allocation of production materials. It provides a new research perspective and theoretical basis for task decomposition and task integration among enterprises.

\section{Conceptual Model of Task Decomposition and Allocation Based on Big Data \\ 2.1. The 5S Management Method and Data Preprocessing}

Data preprocessing using the $5 S$ management method includes five elements. The first element is Seiri, which refers to the selection of the people and things involved by retaining the necessary ones and eliminating the rest. The data collection process may duplicate information for incomplete manufacturing service providers according to the data source, to determine its degree of importance. This includes the acquisition process of the repeated collection and merging of multiple sources of data, the retrieval error dataset, the data collection tools, and in the cause of completeness. All these operations can lead to errors, missing data, or redundancy in the dataset. Therefore, it is necessary to sort out the data, find all repeated or incomplete data through inspection and screening, and then remove them to ensure data accuracy in the database.

The second element is Seiton, which refers to placing the required resources in a fixed position. The data for the manufacturing service providers are named and stored in a fixed location. The operator can name the storage file. The following points must be noted: (1) data from different sources must be marked clearly; (2) multiple folders must be set up according to the complexity of task decomposition and distribution; and (3) these must be stored in a fixed location on the computer for ease of searching and use.

The third element is Seiso, which cleanses the workplace, deletes the original data that does not need to be collected in time, prevents invalid data association, and releases storage space.

The fourth element is Seiketsu, which is a continuation and extension of Seiri, Seiton, and Seiso. It refers to cleaning and tidying the database on the basis of the first three elements. It is a gradual and in-depth process, rather than a specific management link.

The final element is Shitsuke, which indicates that the cleaning process implements multiple steps of data cleaning, develops the practice of fully implementing the rules, and sticks to an appropriate routine.

Data cleaning is the process of repairing or deleting errors, damage, format errors, duplicates, or incomplete data in a data set. First, remove all unnecessary observations from the data set obtained by the crawler; second, identify outliers and check and filter them; third, perform a consistency check and deal with noise. The main process of data cleaning in this research is to write the Mapper part of the three common parts of the MapReduce program, Mapper, Reducer, and Job.

Since most of the data we encounter in real life is generally incomplete, it may lack attribute values or contain only aggregate data. Therefore, the integration of the $5 \mathrm{~S}$ management method into the data-cleaning process can not only standardize the process but also remind researchers to pay attention to the standardization of their own operations. The above steps can reduce the amount of time and effort consumed by the process. Handling 
small details in an operation can remarkably improve the efficiency of data pretreatment and assist researchers in conducting scientific work more efficiently. A brief description of the $5 \mathrm{~S}$ in the entire data-processing procedure is shown in Figure 1.

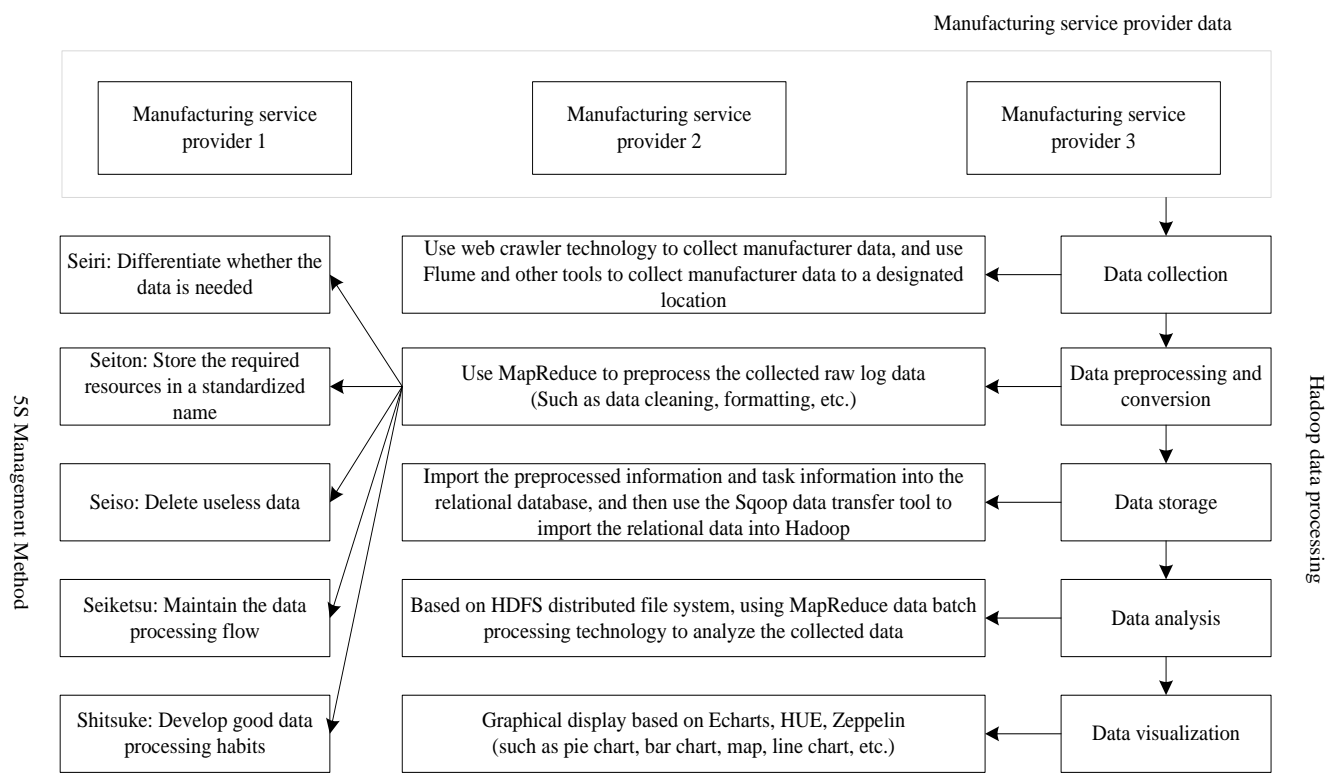

Figure 1. The $5 \mathrm{~S}$ management method and big data processing.

\subsection{Conceptual Model of Manufacturing Task Decomposition and Allocation}

To secure their position in a fiercely competitive market, it is essential for manufacturers to cooperate with regional and cross-regional multi-manufacturing enterprises for efficient production and mutual benefit. However, there are differences in production capacity, production efficiency, and service level among different manufacturing service providers. To cooperate to complete manufacturing tasks more efficiently, a conceptual model of task decomposition and allocation must be constructed.

Several manufacturing enterprises in collaborative production are required for a manufacturer to make full use of their resources, shorten product delivery time, and improve manufacturing efficiency. The information obtained regarding a particular product manufacturing process and production task is split according to the process flow. The production tasks are decomposed into various subtasks and then sent to the distribution unit, which shows the importance of cooperation between various production manufacturers. However, in this process, impracticable planning of the processing sequence and the assembly sequence will lead to cascade adjustment or the redistribution of manufacturing tasks, which will inevitably increase the costs of the cooperating manufacturing service providers. Therefore, to increase the utilization ratio of manufacturing resources and improve manufacturing efficiency, the subtasks must be accurately assigned to suitable suppliers, namely, according to the service standards of the manufacturer, distribution of the corresponding set of tasks, reduction of the rigid requirements for corporate capabilities, improvement of collaborative production between various manufacturing enterprises, and absorption of more small and medium-sized manufacturing service providers to join in collaborative production.

Inspired by the $5 \mathrm{~S}$ management method and data processing, the conceptual model of task decomposition and allocation based on big data can be described as follows: customers release manufacturing demand information, such as product delivery time, quantity, and process requirements, and process massive quantities of data from manufacturing service providers through a $5 \mathrm{~S}$ big data processing mechanism. The conceptual model can be divided into two processing methods, based on different data sources: (1) the internal data of the enterprise is imported directly to the Hadoop platform and transferred to the 
Hadoop distributed file system (HDFS) using the Flume tool to complete data storage; (2) the external data is obtained after data preprocessing (data cleaning) through a web crawler. Then, through data integration, data code and data transformation is stored in the Mysql database in higher quality datasets and passed on to the Hadoop platform via Sqoop tools. Similar to the internal data, the Flume tool is then used to transfer the information to the HDFS. For the processed external data and internal data, the MapReduce-based components Pig and Hive are used to analyze the data of manufacturing service providers, and ECharts and other tools are then used to analyze the results of the data visualization.

In collaborative production activities, it is beneficial to realize more efficient collaborative production among multiple manufacturing enterprises by assigning manufacturing tasks according to their production capacity levels. The manufacturing service provider information obtained by big data technology can be used as a reference for the evaluation criteria and scale-scoring of manufacturing service providers, laying a foundation for subsequent research on selecting the optimal manufacturing service provider, based on the analytic hierarchy process (AHP). The conceptual model of collaborative production task decomposition and allocation is shown in Figure 2.

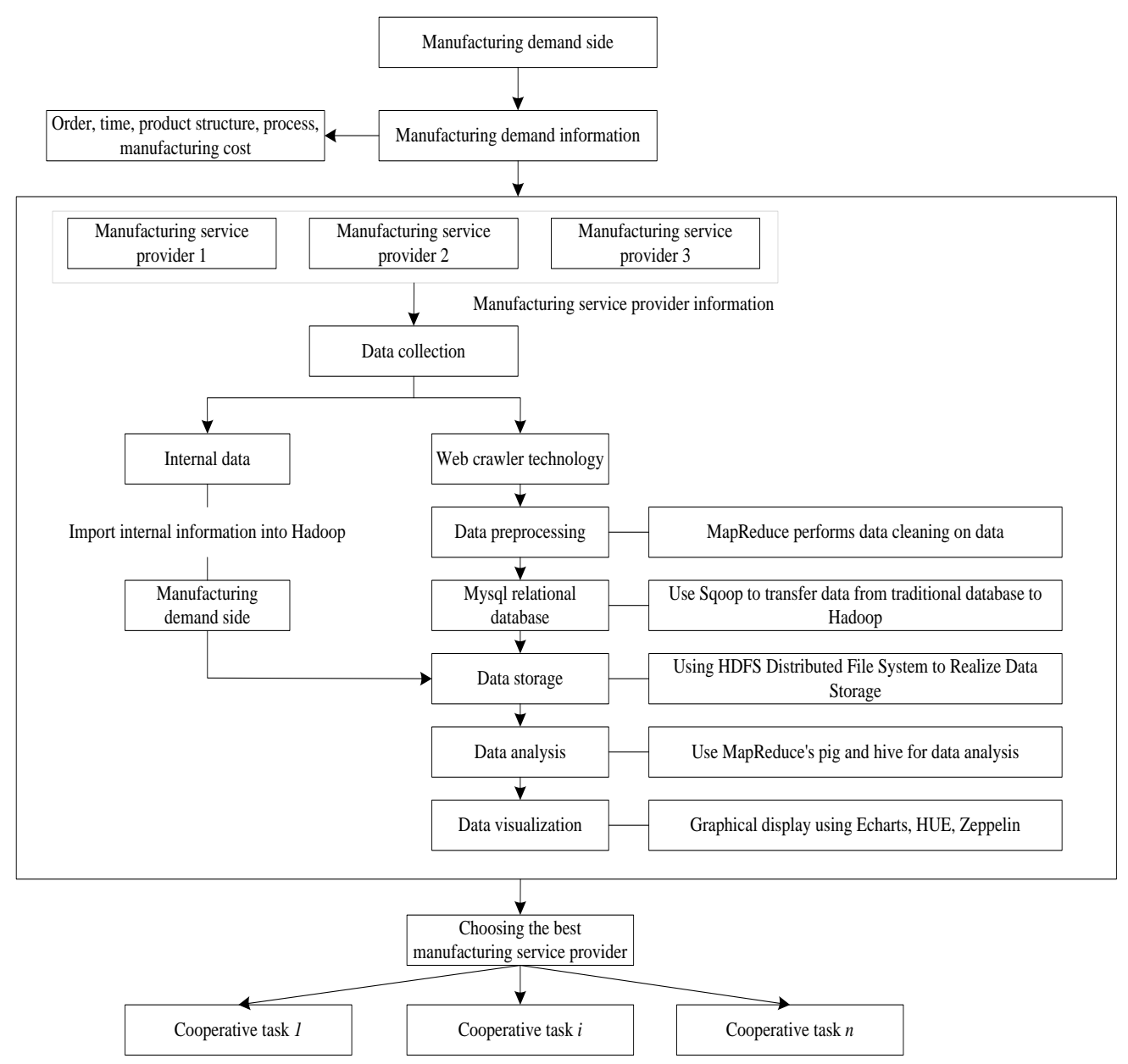

Figure 2. Conceptual model of task decomposition and allocation for collaborative production.

\section{Selection of Manufacturing Service Providers}

This section provides a precise description of the experimental results, their interpretation, and the experimental conclusions.

A big data processing mechanism is used to process the information from candidate manufacturing service providers, from which accurate and perfect data are obtained. Based on this, we invited technical experts from the industry, scientific research institutes, and technical workers of production lines to form expert groups for evaluation. The design of 
relevant indicators was summarized into a questionnaire, and each indicator was scored by combining online and offline methods. The scoring results were collected and summarized after removing the lowest and highest scores. Then, the average score of each indicator and the weight of each indicator were calculated through the AHP to obtain the evaluation results of each manufacturing service provider (see Appendix A for further details).

In his reading of both the domestic and foreign literature, G.W. Dickson [23] summarized the initial version of the evaluation indicator system in his earliest research in light of the consideration of the characteristics of collaboration between supplier production, manufacturing and service. In the process of selecting suppliers, it is necessary to pay attention to close integration and increase evaluation indicators, in line with their own needs and development status. Therefore, the supplier selection process must pay attention to manufacturing and services in relation to financial capacity, product quality, supply price, supply ability and technical capability, customer service level and cooperation potential. The supplier hierarchy model is shown in Figure 3.

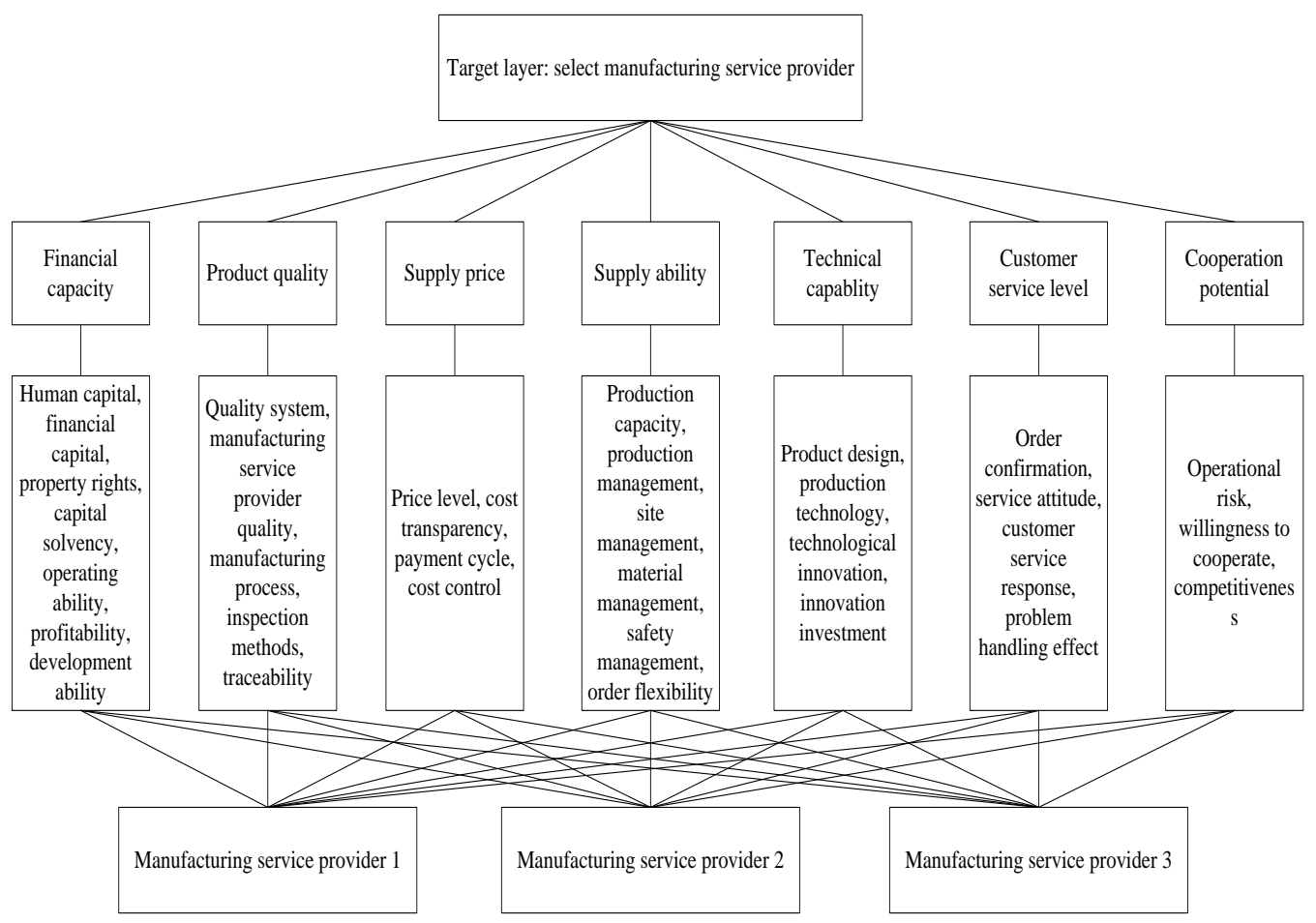

Figure 3. Manufacturing service provider hierarchy model.

In accordance with the AHP, the seven criterion-level indicators of the three candidate manufacturing suppliers are scored using the 1-9 scale method, and the judgment matrix is obtained by pairwise comparison. Hierarchical single ranking and consistency tests were conducted. Finally, the hierarchical total ranking composite weight table was obtained by a hierarchical total ranking and consistency test, as shown in Appendix A. Table A1 is the pairwise comparison matrix of criterion layer and target layer. The weight of each criterion to the target layer, multiplied by the weight of each indicator to the criterion layer (Tables A2-A8) is the comprehensive weight value in Table A12. Tables A9-A11 show the scores of the three manufacturing service providers. By scoring the three candidate manufacturing service providers and using a weighted comprehensive calculation, it can be seen that manufacturing service provider B has the highest score of 9.048 , the secondhighest is $C$ with 8.594 points, and the lowest score is A with 8.239 points. To facilitate the subsequent calculation example analysis, the scores were normalized, and the final scores of $\mathrm{A}, \mathrm{B}$, and $\mathrm{C}$ were $0.318,0.350$, and 0.332 , respectively. The weighted comprehensive scores of each index for the three manufacturing service providers are shown in Figure 4. 


\section{Comprehensive score of manufacturing service providers}

- Manufacturing Service Provider A

- Manufacturing Service Provider C

— Manufacturing Service Provider B

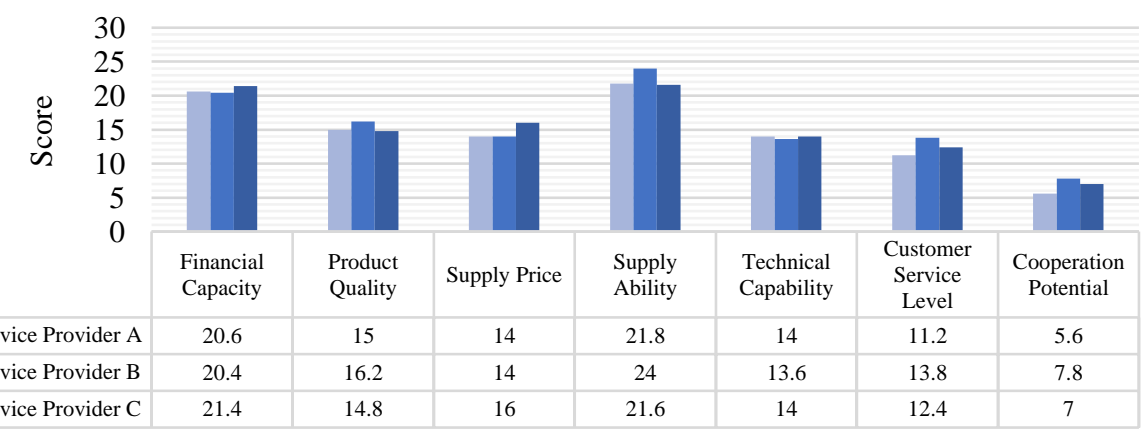

Criterion level index

Figure 4. Comprehensive scores of manufacturing service providers.

As shown in Figure 4, manufacturing service provider B offers the advantages of product quality, delivery capacity, customer service level, and cooperation potential. Manufacturing service provider $\mathrm{C}$ offers the obvious advantage of corporate financial strength, and manufacturing service providers $\mathrm{A}$ and $\mathrm{C}$ both offer the same technical advantages.

\section{Mathematical Model of Task Decomposition and Assignment}

\subsection{Problem Description}

For multiple manufacturing enterprises to conduct collaborative production, every enterprise seeks to maximize its economic benefits as the goal. The pursuit of economic efficiency maximization often leads to a drop in product quality and service levels; therefore, the collaborative manufacturing task decomposition and distribution solutions in the enterprise also need to ensure product quality and service level. Based on the data obtained from big data analysis, this model determines the values of the relevant parameters in the model and obtains specific decomposition and allocation methods for collaborative production tasks. The model aims to adjust the structure of the traditional manufacturing industry in the shortest time and within a reasonable budget, and realizes the rational allocation of resources.

\subsection{Model Assumptions}

In order to achieve the shortest time, reasonable cost and higher service evaluation, to achieve structural adjustment and reasonable allocation of resources, the following assumptions are made:

Hypothesis 1 (H1). The weight values of the three manufacturing service providers will be used to allocate tasks scientifically and reasonably to improve efficiency because the optimal manufacturing service providers have been selected in the previous section and their weight ranking has been obtained.

Hypothesis 2 (H2). The co-production task considers only the production of one part of the product.

Hypothesis 3 (H3). The final assembly step of the product is performed by the manufacturing service provider responsible for the final collaborative production task. The total time required for the entire production task depends mainly on the mode of production. If the production task is linear, the total time is the sum of the time spent on the manufacturing and transportation of a single production task. If the production task is parallel production, the total time depends on the 
manufacturing service provider, which requires more processing time in the parallel production process. The cost required to complete the production task is composed of two parts: the cost generated by manufacturing and the cost generated by transportation.

\subsection{Objective Function}

The parameter variables to be listed for the model and their meanings are shown in Table 1, below.

Table 1. Symbols and their meanings.

\begin{tabular}{|c|c|}
\hline Variable & Significance \\
\hline$R$ & Revenue after a product is sold \\
\hline C & The total cost of carrying out manufacturing activities in a manufacturing firm \\
\hline$Q$ & The profit generated when $i$ carries out production activities can be expressed by $R-C$ \\
\hline$\widetilde{N}$ & The number of products sold in a collaborative production activity \\
\hline$N_{i j}$ & The quantity produced by manufacturing service provider $i$ to complete production task $j$ \\
\hline$P$ & The price at which a product is sold in a collaborative production activity \\
\hline$i$ & Manufacturing service providers participating in collaborative production, $i=1,2, \ldots, m$ \\
\hline$j$ & Cooperate with assigned tasks in production, $j=1,2, \ldots, n$ \\
\hline T & The total time it takes a manufacturing firm to complete manufacturing \\
\hline$x_{i j}$ & $\begin{array}{l}\text { 1, Manufacturing service provider } i \text { is assigned to a collaborative production task } j \text {, and } N_{i j} \text { exists } \\
\text { 0, Manufacturing service provider } i \text { is not assigned to a collaborative production task } j, N_{i j}=0\end{array}$ \\
\hline$T_{t}$ & $\begin{array}{l}\text { The time generated during the transportation of the produced products, including the time required } \\
\text { by } T_{i j} \text { manufacturing service provider } i \text { to complete the production task } j\end{array}$ \\
\hline$T_{d}$ & $\begin{array}{l}\text { The time generated in the transportation process of the produced products, and the time generated in } \\
\text { the transportation process of the product } j \text { produced by } T_{d i j} \text { for manufacturing service provider } i\end{array}$ \\
\hline$C_{d}$ & $\begin{array}{l}\text { The cost generated in the process of product transportation, where } C_{d i j} \text { is the time generated in the } \\
\text { process of manufacturing service provider } i \text { producing product } j\end{array}$ \\
\hline$C_{m}$ & $\begin{array}{l}\text { The manufacturing cost generated during production or things, where } C_{i j} \text { is the cost required by } \\
\text { manufacturing service provider } i \text { to complete the production task } j\end{array}$ \\
\hline$S$ & Service evaluation of manufacturing service provider \\
\hline$S_{i j}$ & Service evaluation of manufacturing service provider $i$ in completing production task $j$ \\
\hline
\end{tabular}

The manufacturing service provider starts production after the production task is begun. The total manufacturing time, $T$, of the production task includes the manufacturing time, $T_{t}$, and the logistics and transportation time, $T_{d}$, where $T_{d i j}$ is the time required by the product transportation process conducted by the manufacturing service provider, $i$. Therefore, the total manufacturing time, $T$, can be expressed as:

$$
\operatorname{MinT}=T_{t}+T_{d}=\left(\sum_{i=1}^{m} \sum_{j=1}^{n} T_{i j} \times N_{i j}+\sum_{i=1}^{m} \sum_{j=1}^{n} T_{d i j}\right) \times x_{i j}
$$

Production costs are a crucial factor in evaluating manufacturing service providers. The cost of collaborative production activities among multiple manufacturing enterprises is mainly composed of the manufacturing cost, $C_{m}$, and logistics cost, $C_{d}$. The manufacturing cost, $C_{d i j}$, mainly includes the cost of purchasing raw materials, labor cost, raw material loss in the production process, and equipment maintenance cost. Logistics cost refers to the transportation cost generated in the process of product transportation, in which $C_{i j}$ refers to the cost generated in the process of product transportation, produced by the manufacturing service provider, $i$. The function of the production cost is:

$$
\operatorname{MinC}=C_{m}+C_{d}=\left(\sum_{i=1}^{m} \sum_{j=1}^{n} C_{i j} \times N_{i j}+\sum_{i=1}^{m} \sum_{j=1}^{n} C_{d i j}\right) \times x_{i j}
$$

Service quality is mainly reflected in the evaluation, which is relatively subjective. The indicators, as seen in Section 3, show that service quality is mainly reflected by service attitude, customer service response, problem-solving ability, and the effect of 
problem-solving. Let $\omega$ represent the weight coefficients of different manufacturing service providers, $0 \leq \omega_{i} \leq 1$ and $\sum_{i=1}^{q} \omega_{i}=1$.

Therefore, the objective function of service quality can be expressed as:

$$
\operatorname{MaxS}=\omega \frac{S_{i j}}{\sum_{i=1}^{m} S_{i j}}
$$

Normal production activities can be maintained only when the enterprise profits are positive. Therefore, when the enterprise income is greater than the cost, the production plan is feasible. The profit $Q$ generated by production activities can be expressed as $R-C$ [24]. The cost of cooperative production among multiple manufacturing enterprises includes the production and cooperative costs of enterprises. The production cost of an enterprise mainly comes from factors such as purchasing raw materials, hiring employees, resource consumption, logistics cost, and equipment maintenance cost:

$$
\operatorname{Max} Q=R-C=N \times P-C=\sum_{i=1}^{m} \sum_{j=1}^{n} N_{i j} \times P-\sum_{i=1}^{m} \sum_{j=1}^{n} N_{i j} \times C_{i j}-\sum_{i=1}^{m} C_{d i j}
$$

\subsection{Constraints}

The constraints of collaborative production scheduling among multi-manufacturing enterprises include the start and end dates of orders, production capacity and undertaking capacity of specialized units, production quantity and working hours, production income and cost, the distance between enterprises, and service quality. The main constraints are as follows:

$$
\begin{gathered}
T \leq T_{\max } \\
C \leq C_{\max } \\
S_{\min } \leq S \\
N \times P \geq \sum_{i=1}^{m} \sum_{j=1}^{n} N_{i j} \times C_{i j}+\sum_{i=1}^{m} C_{d i j} \\
\sum_{j=1}^{n} x_{i j}=1, i=1,2, \ldots, m
\end{gathered}
$$

Equation (5) indicates that the total time of actual collaborative production cannot exceed the delivery time required by the demander. Equation (6) requires that the actual cost of production should not be higher than the total maximum cost required by the manufacturing service provider. Equation (7) indicates that the quality of service provided in the service process cannot be less than the minimum quality of service required. Equation (8) indicates that normal production activities can be conducted only when the income is greater than the cost; otherwise, a collaborative production task cannot be established. Formula (9) restrains the collaborative task in collaborative production activities, and one collaborative task is assigned to only one manufacturer for production.

\section{Test of the Mathematical Model of Task Decomposition and Assignment}

Using the mobile phone manufacturing industry as an example, the key link in the manufacturing process of mobile phones is printed circuit boards (PCBs). The cooperative production task of a PCB assembly can be divided into: (1) task $H_{1}$ : PCB board loading; (2) task $H_{2}$ : printing machine to print solder paste; (3) task $H_{3}$ : SMT machine to paste electronic components; (4) task $H_{4}$ : reflux furnace welding; (5) task $H_{5}$ : semi-finished product test of the production task. 
In this example, currently, 50 printed circuit boards need to be processed. After preliminary screening, there were three manufacturing service providers: $P_{1}, P_{2}$, and $P_{3}$. The manufacturing service providers for each collaborative production task are selected from these three; that is, all three manufacturing service providers are capable of completing the above five production tasks. It can be seen that our goal is to successfully assign five collaborative production tasks to these candidate manufacturing service providers, and the five processing tasks in the task set $\left\{\mathrm{H}_{1}, \mathrm{H}_{2}, \mathrm{H}_{3}, \mathrm{H}_{4}, \mathrm{H}_{5}\right\}$ will be completed according to number.

In Table 2, the second column lists the number of days required by the three manufacturing service providers to complete the five products, shown in days. The third column is the cost quoted by the three manufacturing service providers to complete the five products, taking the production price per square meter of low-end circuit boards of mobile phones as a reference, in yuan (CNY). Crawler is used to obtain the specific figures, and then the $5 \mathrm{~S}$ management method is used to process the data and make reasonable assumptions.

Table 2. Information table of candidate manufacturing service providers participating in collaborative production tasks.

\begin{tabular}{cccccc}
\hline $\begin{array}{c}\text { Production } \\
\text { Task }\end{array}$ & $\begin{array}{c}\text { Time/ } \\
\text { Day }\end{array}$ & Cost (CNY) & $\begin{array}{c}\text { Service } \\
\text { Quality } \\
\text { Evaluation }\end{array}$ & $\begin{array}{c}\text { Location of } \\
\text { Manufacturing } \\
\text { Service } \\
\text { Provider }\end{array}$ & $\begin{array}{c}\text { Manufacturing } \\
\text { Service } \\
\text { Provider }\end{array}$ \\
\hline$H_{1}$ & 2 & 290 & 0.60 & $\mathrm{~A}$ & $P_{1}$ \\
& 2.5 & 220 & 0.80 & $\mathrm{~B}$ & $P_{2}$ \\
$H_{2}$ & 3 & 240 & 0.75 & $\mathrm{C}$ & $P_{3}$ \\
& 3 & 320 & 0.90 & $\mathrm{~A}$ & $P_{1}$ \\
$H_{3}$ & 2 & 170 & 0.70 & $\mathrm{~B}$ & $P_{2}$ \\
& 4 & 250 & 0.80 & $\mathrm{C}$ & $P_{3}$ \\
$H_{4}$ & 7 & 890 & 0.70 & $\mathrm{~A}$ & $P_{1}$ \\
& 6 & 920 & 0.95 & $\mathrm{~B}$ & $P_{2}$ \\
& 15 & 860 & 0.65 & $\mathrm{C}$ & $P_{3}$ \\
$H_{5}$ & 12 & 570 & 0.80 & $\mathrm{~A}$ & $P_{1}$ \\
& 14 & 580 & 0.70 & $\mathrm{~B}$ & $P_{2}$ \\
& 8 & 400 & 0.60 & $\mathrm{C}$ & $P_{1}$ \\
\hline
\end{tabular}

Each time, the person ordering will score the performance of the manufacturing service provider during the process of providing services, with a scoring range of $0-1$ to reflect a customer service level. When there are multiple historical evaluations, the score is the average of the historical evaluations. The data only affects the choice between the three manufacturing service providers and does not affect the validity of the research method. In Tables $2-4$, since the actual situation is very random, with a variety of possible scenarios, values are randomly generated for analysis. The results are only used to draw the conclusions for this case study and have no influence on the whole study.

Table 3. Transport schedule between regions.

\begin{tabular}{cccc}
\hline Transportation/Day & Region A & Region B & Region C \\
\hline Region A & 0 & 2 & 3 \\
Region B & 2 & 0 & 4 \\
Region C & 3 & 4 & 0 \\
\hline
\end{tabular}


Table 4. Transportation cost.

\begin{tabular}{cccc}
\hline Cost (CNY) & Region A & Region B & Region C \\
\hline Region A & 0 & 180 & 260 \\
Region B & 180 & 0 & 320 \\
Region C & 260 & 320 & 0 \\
\hline
\end{tabular}

Table 2 shows the information table for manufacturing service providers participating in collaborative production tasks. Tables 3 and 4 show the time and cost of transportation between the manufacturing service providers.

According to the information for each manufacturing service provider in Tables 2-4, the transportation cost and time between regions, and comprehensively considering the transportation cost and time consumption caused by the different locations of manufacturing service providers, the formula proposed above is used to solve the problem of optimal production resource allocation of the PCB manufacturing process in the mobile phone manufacturing industry.

In the example given in the calculation analysis, the first step is to determine the model of the indicators. Using the manufacturing process of a printed circuit board as an example, the number of customer orders is $n=100$, and the product sales price is $p=1000$, according to the agreement between the manufacturing service provider and the customer. Based on the data, it is calculated that the longest time spent in this case study is 44 , and the minimum service quality is 3.05 . As the data, in this case, is only used for calculation and analysis, there is no external demand from the demand side of the production service. For the convenience of calculation, we set $T_{\max }$ to 44 and $S_{\min }$ to 3.05. Similarly, according to the orders of magnitude of cost and profit in the case study, it is reasonable to assume that $C_{\max }=10,000$ and $Q_{\max }=100,000$. This represents the weight coefficients of different manufacturing service providers in the objective function of the quality of service. In Section 3, the weight coefficients of three manufacturing service providers are normalized, and three different $W$ values are obtained, with two decimal values reserved: $\omega_{1}=0.32$, $\omega_{2}=0.35$, and $\omega_{3}=0.33$.

In the initial parameter setting of the genetic algorithm, the population size was set as popsize $=120$, the maximum number of iterations was set as maxGen $=50$, the crossover probability, $P_{c}=0.8$, and the mutation probability, $P_{m}=0.1$. Finally, the optimal number of days is six, and the lowest cost is 3260 (Algorithms A1 and A2 show the solution of genetic algorithm for this case, see Appendix B for further details).

In general, genetic algorithms randomly generate individuals as the initial population. A co-production task, $H_{\mathrm{j}}$, is co-produced by only one manufacturing service provider corresponding to chromosome $\mathrm{x}_{\mathrm{i}}$; that is, co-production task $H_{1}$ is co-produced by the manufacturing service provider corresponding to the serial number of the first chromosome $\mathrm{x}_{1}$. According to the three manufacturing service providers, the serial number of the initial set is numbered from 1 to 3 , and the randomly generated initial population is shown in Figure 5.

\begin{tabular}{|c|c|c|c|c|c|c|c|}
\hline 2 & 3 & 1 & $\cdots$ & $\cdots$ & 1 & 3 & 1 \\
\hline & $\begin{array}{l}\text { Indicates that the first collaborative production task is collaboratively } \\
\text { produced by the manufacturing service provider with serial number } 2\end{array}$
\end{tabular}

Figure 5. Initial population.

Fitness is used to measure the performance of each individual in the population relatively accurately, and individuals with greater fitness are more likely to pass on their genes to the next generation. According to the research content, the service of the manufacturing service provider is taken as the optimization target. At the same time, the profit generated 
by limited production activities is the highest, and the decision variables, $N, P$, and $C_{0}$. $\alpha 1, \alpha 2$ and $\alpha 3$, reflect the importance of profit, service level and time, respectively. If profit is more important and time efficiency is second, then $\alpha 1>\alpha 3>\alpha 2$. Considering the relationship between functions, the fitness function is defined as:

$$
f(i)=\alpha_{1} \frac{Q_{i}}{Q_{\max }}+\alpha_{2} \frac{S_{i}}{S_{\max }}+\alpha_{3} \frac{T_{i}}{T_{\min }}
$$

Selection depends on individual fitness values to calculate the probability of each individual's genetic code appearing in the offspring, and the calculation randomly selects each individual to form the offspring population according to this probability. For example, we suppose that the number of individuals in each generation is $M$, and the fitness of each individual is $f g$. Then, the probability of $g$ being selected is:

$$
f_{g} / \sum_{g=1}^{M} f_{g}
$$

The research was carried out in a single-point crossing way. The individual gene code is in pairs, and a crossover location is generated with this opportunity. Two individuals can exchange their genetic code at the crossover location, thus forming two new offspring individuals. The principle of the crossover process is shown in Figures 6 and 7. Mutations in genetic algorithms are achieved by changing a location on the chromosomes, or a location in their genes, as shown in Figure 8.

\begin{tabular}{l}
\begin{tabular}{|l|l|l|l|l|l|l|}
\hline 1 & 0 & 1 & $\cdots$ & 1 & 0 & 0 \\
\hline 1 & 0 & 0 & $\cdots$ & 0 & 0 & 1 \\
\hline
\end{tabular} \\
\hline
\end{tabular}

Parent Individual 1

Figure 6. Parent individual binary code string.

\begin{tabular}{l}
\begin{tabular}{l|l|l|l|l|l|l|}
\hline 1 & 0 & 1 & $\cdots$ & 0 & 0 & 1 \\
\hline 1 & 0 & 0 & $\cdots$ & 1 & 0 & 0 \\
\hline
\end{tabular} \\
\hline
\end{tabular}

Offspring Individual 1

Figure 7. Offspring individual binary code string.

Mutation point

\begin{tabular}{|l|l|l|l|l|l|l|}
\hline 1 & 0 & 0 & $\cdots$ & 0 & 0 & 1 \\
\hline 1 & 1 & 0 & $\cdots$ & 0 & 0 & 1 \\
\hline
\end{tabular}
\begin{tabular}{|l|l|l|l|l|l|}
\hline \\
\hline
\end{tabular}

Before mutation

After mutation

Figure 8. Mutation operation.

By referring to the work of Kucuksayacigil [25], research into genetic algorithm parameter fine-tuning can result in a high crossover rate and low mutation rate, and the solving effect is good. Therefore, the crossover rate and mutation rate are set as 0.8 and 0.05 . 
Variations in the genetic algorithm are accomplished by changing a certain position on the chromosome or genes at certain positions, as shown in Figure 8.

The termination condition selects the method by which the maximum iteration algebra is set. The flow chart of the specific calculation process of function-solving using the genetic algorithm is shown in Figure 9.

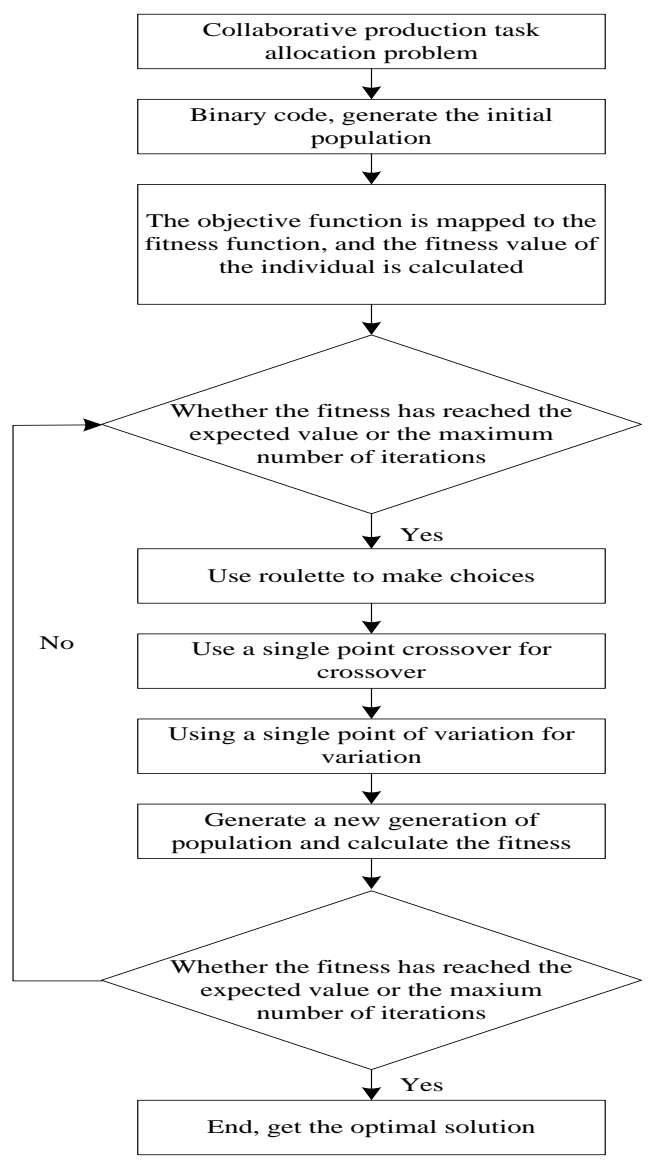

Figure 9. Genetic algorithm-solving process.

The calculation results show that the task $H_{1}$ PCB board-loading is completed by $P_{3}$. The task $H_{2}$ printing machine is used to print solder paste to $P_{3}$; the task $H_{3}$ SMT electronic components are completed by $P_{1}$; the task $H_{4}$ reflux furnace welding is completed by $P_{2}$; the task $\mathrm{H}_{5}$ semi-finished product test is completed by $P_{2}$. Through the above arrangement, the PCB assembly process can be guaranteed to reach the optimal ratio of cooperative production via multiple manufacturing enterprises and to achieve a balance between the economic benefits and service quality of manufacturing enterprises.

\section{Conclusions}

Focusing on the three parts of big data processing, manufacturing service provider selection, and the task allocation model of collaborative production, the main research work and conclusions are as follows:

(1) Big data technology was used to screen the information of candidate manufacturing service providers. The current popular big data platform, Hadoop processing technology, is used to screen candidate manufacturing service providers, and the $5 \mathrm{~S}$ management method is integrated into the data processing. In addition, the specific process of data cleaning and conversion is established to improve the efficiency of data processing for manufacturing service providers. 
(2) Based on the understanding and analysis of the research results in related fields, AHP is selected to screen the optimal manufacturing service provider; the fuzzy evaluation indicators, due to the enterprise's requirements or the difficulty of refining evaluation indicators, are quantified to render them more three-dimensional. One of the resulting three candidate manufacturing service providers is selected as the optimal service provider, according to the index weight ranking after normalization.

(3) This paper builds a task allocation model that considers time, manufacturing cost, product quality, service quality, and other indicators, and refines the assumptions, parameter settings, objective functions, constraint conditions, and other issues of the task decomposition and allocation model for collaborative production among multiple manufacturing enterprises in the big data environment. Substituting specific data into the model solution proved the validity of the established model scheme.

(4) A closed loop between big data technology and task allocation was completed. After data cleaning, the information from manufacturing service providers was integrated, and the AHP was used to quantify the indicators, which provided a new idea for the preparation of efficient collaborative production among multiple manufacturing enterprises. In terms of actual cooperative production activities among multi-manufacturing enterprises, production tasks are appropriately allocated to manufacturing service providers with different production capacities, to provide more opportunities for small- and medium-sized manufacturing enterprises to participate in the task of mass production.

At the same time, this study also has some limitations. The goal of this study is to achieve the goals of the shortest total time frame, lowest total cost and high overall service level in multi-enterprise cooperative production. As a result, the time frame and cost of an individual enterprise is rarely considered. In reality, due to the independence of each enterprise, because the task assigned is not a production plan that maximizes the firm's profits, the individual firm is likely to withdraw from production. Therefore, in future studies, we can adopt additional constraints that consider the profits of individual firms. In the case of the lowest total cost, the method of offering some compensation to the enterprises that make "sacrifices" makes the research results more widely applicable.

Author Contributions: X.L. contributed to the writing of the first draft of this study, model building, case analysis, and analysis of relevant experimental results; F.L. contributed to the concept, method design, research work, and experimental analysis; Y.Y. contributed to the background research of this study and put forward constructive suggestions for revision. Y.X. and Y.Z. helped to analyze and make important suggestions for the framework of this article and to make some modifications to the original draft. All authors have read and agreed to the published version of the manuscript.

Funding: This study was supported by the National Social Science Fund of China, Research on the National Social Science Fund of China (20BJY185), Beijing Social Science Foundation(19ZDA12), Project of 2020 "Shipei plan" of Beijing Wuzi University, Beijing Collaborative Innovation Center for Intelligent Logistics System (BILSCI-2019KF-12), Jiangsu Key Laboratory of Transportation and Security (TTS2018-02), and Natural Science Foundation of Shaanxi Province (2021JM-146).

Institutional Review Board Statement: Not applicable.

Informed Consent Statement: Not applicable.

Data Availability Statement: Not applicable.

Conflicts of Interest: The authors declare no conflict of interest. 


\section{Appendix A}

Table A1. Pairwise comparison matrix of criterion layer to target layer.

\begin{tabular}{cccccccc}
\hline $\begin{array}{c}\text { Select Manufacturing } \\
\text { Service Provider }\end{array}$ & $\begin{array}{c}\text { Financial } \\
\text { Capacity }\end{array}$ & $\begin{array}{c}\text { Product } \\
\text { Quality }\end{array}$ & $\begin{array}{c}\text { Supply } \\
\text { Price }\end{array}$ & $\begin{array}{c}\text { Supply } \\
\text { Ability }\end{array}$ & $\begin{array}{c}\text { Technical } \\
\text { Capability }\end{array}$ & $\begin{array}{c}\text { Customer } \\
\text { Service Level }\end{array}$ & $\begin{array}{c}\text { Cooperation } \\
\text { Potential }\end{array}$ \\
\hline Financial Capacity & 1 & $1 / 3$ & $1 / 3$ & $1 / 3$ & 1 & 5 & 2 \\
Product Quality & 3 & 1 & 1 & 3 & 5 & 5 & 5 \\
Supply Price & 3 & 1 & 1 & $1 / 3$ & 5 & 5 & 2 \\
Supply Ability & 3 & $1 / 3$ & 3 & 1 & 5 & 1 & 1 \\
Technical Capability & 1 & $1 / 5$ & $1 / 5$ & $1 / 5$ & 1 & 1 & 1 \\
Customer Service Level & $1 / 5$ & $1 / 5$ & $1 / 5$ & $1 / 5$ & 1 & 1 \\
Cooperation Potential & $1 / 2$ & $1 / 5$ & $1 / 4$ & $1 / 2$ & 19 & & 23 \\
Sum & $82 / 7$ & $13 / 4$ & 6 & $39 / 7$ & 19 & \\
\hline
\end{tabular}

Table A2. Financial capacity index judgment matrix and weight value.

\begin{tabular}{|c|c|c|c|c|c|c|c|c|}
\hline Financial Capacity & $\begin{array}{l}\text { Human } \\
\text { Capital }\end{array}$ & $\begin{array}{l}\text { Financial } \\
\text { Capital }\end{array}$ & $\begin{array}{l}\text { Equity } \\
\text { Capital }\end{array}$ & $\begin{array}{c}\text { Debt Paying } \\
\text { Ability }\end{array}$ & $\begin{array}{l}\text { Ability to } \\
\text { Operate }\end{array}$ & Profitability & $\begin{array}{l}\text { Development } \\
\text { Capacity }\end{array}$ & $\begin{array}{c}\text { Weight } \\
\text { value }\end{array}$ \\
\hline Human Capital & 1 & $1 / 3$ & 1 & $1 / 3$ & $1 / 4$ & $1 / 5$ & $1 / 3$ & 0.0047 \\
\hline Financial Capital & 3 & 1 & 3 & 1 & $1 / 2$ & $1 / 3$ & $1 / 3$ & 0.108 \\
\hline Equity Capital & 1 & $1 / 3$ & 1 & $1 / 3$ & $1 / 3$ & $1 / 3$ & $1 / 5$ & 0.046 \\
\hline Debt-Paying Ability & 3 & 1 & 3 & 1 & 1 & 1 & $1 / 3$ & 0.140 \\
\hline Ability to Operate & 4 & 2 & 3 & 1 & 1 & 1 & 2 & 0.232 \\
\hline Profitability & 5 & 3 & 5 & 1 & $1 / 2$ & $1 / 2$ & $1 / 2$ & 0.182 \\
\hline Development Capacity & 3 & 3 & 5 & 3 & $1 / 2$ & $1 / 2$ & 1 & 0.241 \\
\hline
\end{tabular}

$\lambda \max =7.421, \mathrm{CI}=0.07, \mathrm{RI}=1.36, \mathrm{CR}=0.05<1$, Consistency test passed.

Table A3. Product quality index judgment matrix and weight value.

\begin{tabular}{|c|c|c|c|c|c|c|}
\hline Product Quality & $\begin{array}{l}\text { Quality } \\
\text { System }\end{array}$ & $\begin{array}{c}\text { Quality of } \\
\text { Manufacturing } \\
\text { Service Provider }\end{array}$ & $\begin{array}{l}\text { Manufacturing } \\
\text { Process }\end{array}$ & $\begin{array}{c}\text { Test } \\
\text { Indicators }\end{array}$ & Traceability & $\begin{array}{l}\text { Weight } \\
\text { Value }\end{array}$ \\
\hline Quality System & 1 & $1 / 3$ & $1 / 3$ & $1 / 2$ & 3 & 0.125 \\
\hline $\begin{array}{l}\text { Quality of Manufacturing } \\
\text { Service Provider }\end{array}$ & 3 & 1 & $1 / 2$ & $1 / 2$ & 3 & 0.205 \\
\hline Manufacturing Process & 3 & 2 & 1 & 3 & 4 & 0.388 \\
\hline Test Indicators & 2 & 2 & $1 / 3$ & 1 & 2 & 0.208 \\
\hline Traceability & $1 / 3$ & $1 / 3$ & $1 / 4$ & $1 / 2$ & 1 & 0.073 \\
\hline
\end{tabular}

$\lambda \max =5.33, \mathrm{CI}=0.08, \mathrm{RI}=1.12, \mathrm{CR}=0.07<1$, Consistency test passed.

Table A4. Supply price index judgment matrix and weight value.

\begin{tabular}{cccccc}
\hline Supply Price & Price Level & $\begin{array}{c}\text { Cost } \\
\text { Transparency }\end{array}$ & $\begin{array}{c}\text { Payment } \\
\text { Period }\end{array}$ & $\begin{array}{c}\text { Cost } \\
\text { Control }\end{array}$ & Weight Value \\
\hline Price Level & 1 & 3 & 2 & 2 & 0.406 \\
Cost Transparency & $1 / 3$ & 1 & $1 / 3$ & $1 / 3$ & 0.098 \\
Payment Period & $1 / 2$ & 3 & 1 & 2 & 0.287 \\
Cost Control & $1 / 2$ & 3 & $1 / 2$ & 1 & 0.208 \\
\hline
\end{tabular}

$\lambda \max =4.12, \mathrm{CI}=0.04, \mathrm{RI}=0.89, \mathrm{CR}=0.04<1$, Consistency test passed.

Table A5. Supply ability index judgment matrix and weight value.

\begin{tabular}{cccccccc}
\hline $\begin{array}{c}\text { Supply } \\
\text { Ability }\end{array}$ & $\begin{array}{c}\text { Production } \\
\text { Capacity }\end{array}$ & $\begin{array}{c}\text { Production } \\
\text { Management }\end{array}$ & $\begin{array}{c}\text { Production } \\
\text { Capacity }\end{array}$ & $\begin{array}{c}\text { Production } \\
\text { Management }\end{array}$ & $\begin{array}{c}\text { Safety } \\
\text { Management }\end{array}$ & $\begin{array}{c}\text { Order } \\
\text { Flexibility }\end{array}$ & $\begin{array}{c}\text { Weight } \\
\text { Value }\end{array}$ \\
\hline $\begin{array}{c}\text { Production } \\
\text { Capacity }\end{array}$ & 1 & 2 & 3 & 3 & 2 & 3 & 0.310 \\
$\begin{array}{c}\text { Production } \\
\text { Management }\end{array}$ & $1 / 2$ & 1 & $1 / 2$ & 2 & $1 / 2$ & 2 & 0.130 \\
\hline
\end{tabular}


Table A5. Cont.

\begin{tabular}{cccccccc}
\hline $\begin{array}{c}\text { Supply } \\
\text { Ability }\end{array}$ & $\begin{array}{c}\text { Production } \\
\text { Capacity }\end{array}$ & $\begin{array}{c}\text { Production } \\
\text { Management }\end{array}$ & $\begin{array}{c}\text { Production } \\
\text { Capacity }\end{array}$ & $\begin{array}{c}\text { Production } \\
\text { Management }\end{array}$ & $\begin{array}{c}\text { Safety } \\
\text { Management }\end{array}$ & $\begin{array}{c}\text { Order } \\
\text { Flexibility }\end{array}$ & $\begin{array}{c}\text { Weight } \\
\text { Value }\end{array}$ \\
\hline $\begin{array}{c}\text { Production } \\
\text { Capacity }\end{array}$ & $1 / 3$ & 2 & 1 & 2 & $1 / 3$ & 3 & 0.157 \\
$\begin{array}{c}\text { Production } \\
\text { Management }\end{array}$ & $1 / 3$ & $1 / 2$ & $1 / 2$ & 1 & $1 / 2$ & 3 & 0.106 \\
$\begin{array}{c}\text { Safety } \\
\text { Management } \\
\text { Order }\end{array}$ & $1 / 2$ & 2 & 3 & 2 & 1 & $1 / 3$ & 0.230 \\
Flexibility & $1 / 3$ & $1 / 2$ & $1 / 3$ & $1 / 3$ & 0.063 \\
\hline
\end{tabular}

$\lambda \max =6.36, \mathrm{CI}=0.07, \mathrm{RI}=1.26, \mathrm{CR}=0.05<1$, Consistency test passed.

Table A6. Technical Capability index judgment matrix and weight value.

\begin{tabular}{cccccc}
\hline $\begin{array}{c}\text { Technical } \\
\text { Capability }\end{array}$ & $\begin{array}{c}\text { Product } \\
\text { Design }\end{array}$ & $\begin{array}{c}\text { Production } \\
\text { Technology }\end{array}$ & $\begin{array}{c}\text { Technological } \\
\text { Innovation }\end{array}$ & $\begin{array}{c}\text { Innovation } \\
\text { Investment }\end{array}$ & $\begin{array}{c}\text { Weight } \\
\text { Value }\end{array}$ \\
\hline Product Design & 1 & 2 & 2 & 2 & 0.383 \\
Production Technology & $1 / 2$ & 1 & 3 & 2 & 0.299 \\
Technological Innovation & $1 / 2$ & $1 / 3$ & 1 & $1 / 2$ & 0.125 \\
Innovation Investment & $1 / 2$ & $1 / 2$ & 2 & 1 & 0.190 \\
\hline
\end{tabular}

$\lambda \max =4.14, \mathrm{CI}=0.04, \mathrm{RI}=0.89, \mathrm{CR}=0.05<1$, Consistency test passed.

Table A7. Customer service level index judgment matrix and weight value.

\begin{tabular}{cccccc}
\hline Customer Service Level & $\begin{array}{c}\text { Order } \\
\text { Confirmation }\end{array}$ & $\begin{array}{c}\text { Service } \\
\text { Attitude }\end{array}$ & $\begin{array}{c}\text { Customer Service } \\
\text { Response }\end{array}$ & $\begin{array}{c}\text { Problem } \\
\text { Handling Effect }\end{array}$ & $\begin{array}{c}\text { Weight } \\
\text { Value }\end{array}$ \\
\hline Order Confirmation & 1 & 2 & 2 & 3 & 0.419 \\
Service Attitude & $1 / 2$ & 1 & $1 / 2$ & $1 / 2$ & 0.137 \\
Customer Service Response & $1 / 2$ & 2 & 1 & $1 / 2$ & 0.195 \\
Problem-Handling Effect & $1 / 3$ & 2 & 2 & 1 & 0.248 \\
\hline
\end{tabular}

$\lambda \max =4.21, \mathrm{CI}=0.07, \mathrm{RI}=0.89, \mathrm{CR}=0.08<1$, Consistency test passed.

Table A8. Cooperation potential index judgment matrix and weight value.

\begin{tabular}{ccccc}
\hline Cooperation Potential & Business Risk & Cooperation Potential & Competitiveness & Weight Value \\
\hline Business Risk & 1 & 3 & 3 & 0.588 \\
Cooperation Potential & $1 / 3$ & 1 & $1 / 2$ & 0.159 \\
Competitiveness & $1 / 3$ & 2 & 1 & 0.251 \\
\hline
\end{tabular}

$\lambda \max =3.05, \mathrm{CI}=0.02, \mathrm{RI}=0.52, \mathrm{CR}=0.05<1$, Consistency test passed.

Table A9. Evaluation of manufacturing service provider A.

\begin{tabular}{|c|c|c|}
\hline Manufacturing Service Provider A & Indicators & Synthesis Score \\
\hline \multirow{7}{*}{ Financial Capacity } & Human Capital & 2 \\
\hline & Financial Capital & 2.6 \\
\hline & Equity Capital & 3 \\
\hline & Debt Paying Ability & 3 \\
\hline & Ability to Operate & 3 \\
\hline & Profitability & 3.6 \\
\hline & Development Capacity & 3.4 \\
\hline \multirow{5}{*}{ Product Quality } & Quality System & 3.2 \\
\hline & $\begin{array}{c}\text { Quality of Manufacturing Service } \\
\text { Provider }\end{array}$ & 3 \\
\hline & Manufacturing Process & 2.8 \\
\hline & Test Indicators & 3 \\
\hline & Traceability & 3 \\
\hline
\end{tabular}


Table A9. Cont.

\begin{tabular}{|c|c|c|}
\hline Manufacturing Service Provider A & Indicators & Synthesis Score \\
\hline \multirow{4}{*}{ Supply Price } & Price Level & 4 \\
\hline & Cost Transparency & 3 \\
\hline & Payment Period & 3 \\
\hline & Cost Control & 4 \\
\hline \multirow{6}{*}{ Supply Ability } & Production Capacity & 5 \\
\hline & Production Management & 4 \\
\hline & Production Capacity & 3.6 \\
\hline & Production Management & 3 \\
\hline & Safety Management & 3.2 \\
\hline & Order Flexibility & 3 \\
\hline \multirow{4}{*}{ Technical Capability } & Product Design & 3.8 \\
\hline & Production Technology & 3 \\
\hline & Technological Innovation & 3.2 \\
\hline & Innovation Investment & 4 \\
\hline \multirow{4}{*}{ Customer Service Level } & Order Confirmation & 3 \\
\hline & Service Attitude & 2 \\
\hline & Customer Service Response & 3 \\
\hline & Problem Handling Effect & 3.2 \\
\hline \multirow{3}{*}{ Cooperation Potential } & Business Risk & 3 \\
\hline & Cooperation Potential & 2.6 \\
\hline & Competitiveness & 3 \\
\hline
\end{tabular}

Table A10. Evaluation of manufacturing service provider B.

\begin{tabular}{|c|c|c|}
\hline Manufacturing Service Provider B & Indicators & Synthesis Score \\
\hline \multirow{7}{*}{ Financial Capacity } & Human Capital & 3 \\
\hline & Financial Capital & 2.6 \\
\hline & Equity Capital & 3.2 \\
\hline & Debt Paying Ability & 2.8 \\
\hline & Ability to Operate & 3.2 \\
\hline & Profitability & 2.6 \\
\hline & Development Capacity & 3 \\
\hline \multirow{5}{*}{ Product Quality } & Quality System & 3.6 \\
\hline & Quality of Manufacturing Service Provider & 3.4 \\
\hline & Manufacturing Process & 3.2 \\
\hline & Test Indicators & 2.8 \\
\hline & Traceability & 3.2 \\
\hline \multirow{4}{*}{ Supply Price } & Price Level & 4 \\
\hline & Cost Transparency & 3 \\
\hline & Payment Period & 4 \\
\hline & Cost Control & 3 \\
\hline \multirow{6}{*}{ Supply Ability } & Production Capacity & 5 \\
\hline & Production Management & 4 \\
\hline & Production Capacity & 4 \\
\hline & Production Management & 4 \\
\hline & Safety Management & 4 \\
\hline & Order Flexibility & 3 \\
\hline \multirow{4}{*}{ Technical Capability } & Product Design & 3.2 \\
\hline & Production Technology & 3 \\
\hline & Technological Innovation & 3.4 \\
\hline & Innovation Investment & 4 \\
\hline
\end{tabular}


Table A10. Cont.

\begin{tabular}{ccc}
\hline Manufacturing Service Provider B & Indicators & Synthesis Score \\
\hline & Order Confirmation & 3.2 \\
Customer Service Level & Service Attitude & 3.4 \\
& Customer Service Response & 3.8 \\
\hline & Problem Handling Effect & 3.4 \\
Cooperation Potential & Business Risk & 3.8 \\
& Cooperation Potential & 4 \\
\hline
\end{tabular}

Table A11. Evaluation of manufacturing service provider C.

\begin{tabular}{|c|c|c|}
\hline Manufacturing Service Provider C & Indicators & Synthesis Score \\
\hline \multirow{7}{*}{ Financial Capacity } & Human Capital & 3 \\
\hline & Financial Capital & 3.2 \\
\hline & Equity Capital & 3 \\
\hline & Debt Paying Ability & 3 \\
\hline & Ability to Operate & 3.4 \\
\hline & Profitability & 2.8 \\
\hline & Development Capacity & 3 \\
\hline \multirow{5}{*}{ Product Quality } & Quality System & 2.8 \\
\hline & Quality of Manufacturing Service Provider & 3 \\
\hline & Manufacturing Process & 3 \\
\hline & Test Indicators & 3 \\
\hline & Traceability & 3 \\
\hline \multirow{4}{*}{ Supply Price } & Price Level & 5 \\
\hline & Cost Transparency & 3 \\
\hline & Payment Period & 4 \\
\hline & Cost Control & 4 \\
\hline \multirow{6}{*}{ Supply Ability } & Production Capacity & 5 \\
\hline & Production Management & 4 \\
\hline & Production Capacity & 3 \\
\hline & Production Management & 3.6 \\
\hline & Safety Management & 3 \\
\hline & Order Flexibility & 3 \\
\hline \multirow{4}{*}{ Technical Capability } & Product Design & 3.8 \\
\hline & Production Technology & 3 \\
\hline & Technological Innovation & 3.2 \\
\hline & Innovation Investment & 4 \\
\hline \multirow{4}{*}{ Customer Service Level } & Order Confirmation & 3 \\
\hline & Service Attitude & 3.4 \\
\hline & Customer Service Response & 3 \\
\hline & Problem Handling Effect & 3 \\
\hline \multirow{3}{*}{ Cooperation Potential } & Business Risk & 3 \\
\hline & Cooperation Potential & 3.4 \\
\hline & Competitiveness & 3.6 \\
\hline
\end{tabular}


Table A12. Comprehensive score of three manufacturing service providers.

\begin{tabular}{|c|c|c|c|c|c|c|c|c|}
\hline \multirow{2}{*}{ Criterion } & \multirow{2}{*}{ Index } & \multirow{2}{*}{$\begin{array}{c}\text { Comprehensive } \\
\text { Weight }\end{array}$} & \multicolumn{3}{|c|}{ Original Rating } & \multicolumn{3}{|c|}{ Final Score } \\
\hline & & & A & B & $\mathrm{C}$ & A & B & $\mathrm{C}$ \\
\hline \multirow{7}{*}{$\begin{array}{l}\text { Financial } \\
\text { Capacity }\end{array}$} & Human Capital & 0.005 & 2 & 3 & 3 & 0.010 & 0.015 & 0.015 \\
\hline & Financial Capital & 0.010 & 2.6 & 2.6 & 3.2 & 0.026 & 0.026 & 0.032 \\
\hline & Equity Capital & 0.004 & 3 & 3.2 & 3 & 0.012 & 0.013 & 0.012 \\
\hline & Debt Paying Ability & 0.014 & 3 & 2.8 & 3 & 0.042 & 0.039 & 0.042 \\
\hline & Ability to Operate & 0.023 & 3 & 3.2 & 3.4 & 0.069 & 0.074 & 0.078 \\
\hline & Profitability & 0.018 & 3.6 & 2.6 & 2.8 & 0.065 & 0.047 & 0.050 \\
\hline & Development Capacity & 0.023 & 3.4 & 3 & 3 & 0.078 & 0.069 & 0.069 \\
\hline \multirow{5}{*}{$\begin{array}{l}\text { Product } \\
\text { Quality }\end{array}$} & Quality System & 0.037 & 3.2 & 3.6 & 2.8 & 0.118 & 0.133 & 0.104 \\
\hline & $\begin{array}{l}\text { Quality of Manufacturing } \\
\text { Service Provider }\end{array}$ & 0.060 & 3 & 3.4 & 3 & 0.180 & 0.204 & 0.180 \\
\hline & Manufacturing Process & 0.112 & 2.8 & 3.2 & 3 & 0.314 & 0.358 & 0.336 \\
\hline & Test Indicators & 0.061 & 3 & 2.8 & 3 & 0.183 & 0.171 & 0.183 \\
\hline & Traceability & 0.215 & 3 & 3.2 & 3 & 0.645 & 0.688 & 0.645 \\
\hline \multirow{4}{*}{$\begin{array}{l}\text { Supply } \\
\text { Price }\end{array}$} & Price Level & 0.088 & 4 & 4 & 5 & 0.352 & 0.352 & 0.440 \\
\hline & Cost Transparency & 0.021 & 3 & 3 & 3 & 0.063 & 0.063 & 0.063 \\
\hline & Payment Period & 0.062 & 3 & 4 & 4 & 0.186 & 0.248 & 0.248 \\
\hline & Cost Control & 0.045 & 4 & 3 & 4 & 0.180 & 0.135 & 0.180 \\
\hline \multirow{6}{*}{$\begin{array}{l}\text { Supply } \\
\text { Ability }\end{array}$} & Production Capacity & 0.073 & 5 & 5 & 5 & 0.365 & 0.365 & 0.365 \\
\hline & Production Management & 0.031 & 4 & 4 & 4 & 0.124 & 0.124 & 0.124 \\
\hline & Production Capacity & 0.037 & 3.6 & 4 & 3 & 0.133 & 0.148 & 0.111 \\
\hline & Production Management & 0.025 & 3 & 4 & 3.6 & 0.075 & 0.100 & 0.090 \\
\hline & Safety Management & 0.054 & 3.2 & 4 & 3 & 0.173 & 0.216 & 0.162 \\
\hline & Order Flexibility & 0.015 & 3 & 3 & 3 & 0.045 & 0.045 & 0.045 \\
\hline \multirow{4}{*}{$\begin{array}{l}\text { Technical } \\
\text { Capability }\end{array}$} & Product Design & 0.205 & 3.8 & 3.2 & 3.8 & 0.779 & 0.656 & 0.779 \\
\hline & Production Technology & 0.160 & 3 & 3 & 3 & 0.480 & 0.480 & 0.480 \\
\hline & Technological Innovation & 0.067 & 3.2 & 3.4 & 3.2 & 0.214 & 0.228 & 0.214 \\
\hline & Innovation Investment & & 0.102 & 4 & 4 & 0.408 & 0.408 & 0.408 \\
\hline \multirow{4}{*}{$\begin{array}{c}\text { Customer } \\
\text { Service } \\
\text { Level }\end{array}$} & Order Confirmation & 0.183 & 3 & 3.2 & 3 & 0.549 & 0.586 & 0.549 \\
\hline & Service Attitude & 0.060 & 2 & 3.4 & 3.4 & 0.120 & 0.204 & 0.204 \\
\hline & Customer Service Response & 0.085 & 3 & 3.8 & 3 & 0.255 & 0.323 & 0.255 \\
\hline & Problem-Handling Effect & 0.108 & 3.2 & 3.4 & 3 & 0.346 & 0.367 & 0.324 \\
\hline \multirow{3}{*}{$\begin{array}{l}\text { Cooperation } \\
\text { Potential }\end{array}$} & Business Risk & 0.331 & 3 & 3.8 & 3 & 0.993 & 1.258 & 0.993 \\
\hline & Cooperation Potential & 0.090 & 2.6 & 3.8 & 3.4 & 0.234 & 0.342 & 0.306 \\
\hline & Competitiveness & 0.141 & 3 & 4 & 3.6 & 0.423 & 0.564 & 0.508 \\
\hline \multicolumn{6}{|c|}{ Weight Sorting: $\mathrm{B}>\mathrm{C}>\mathrm{A}$} & 8.239 & 9.048 & 8.594 \\
\hline
\end{tabular}




\section{Appendix B. Genetic Algorithm}

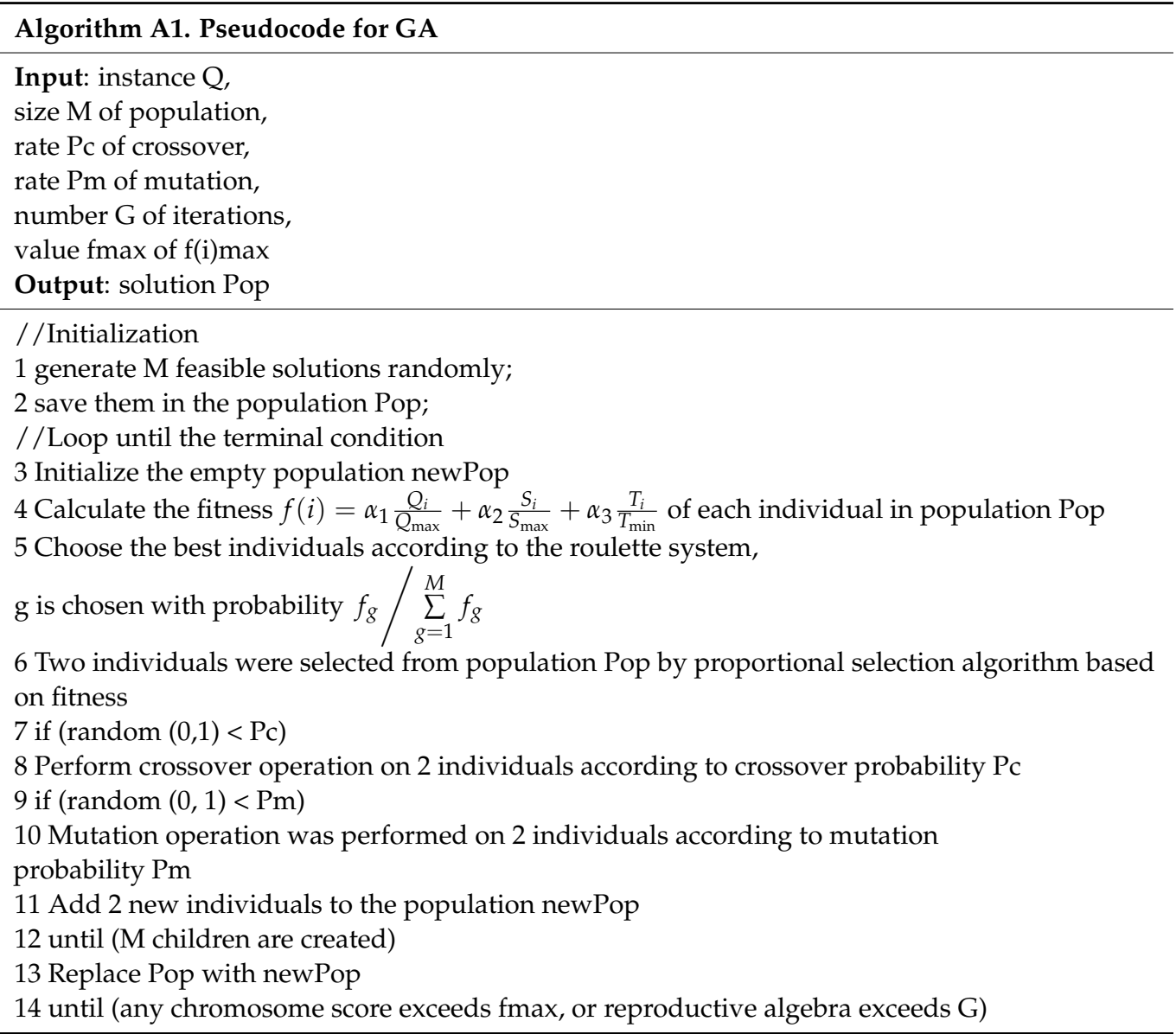




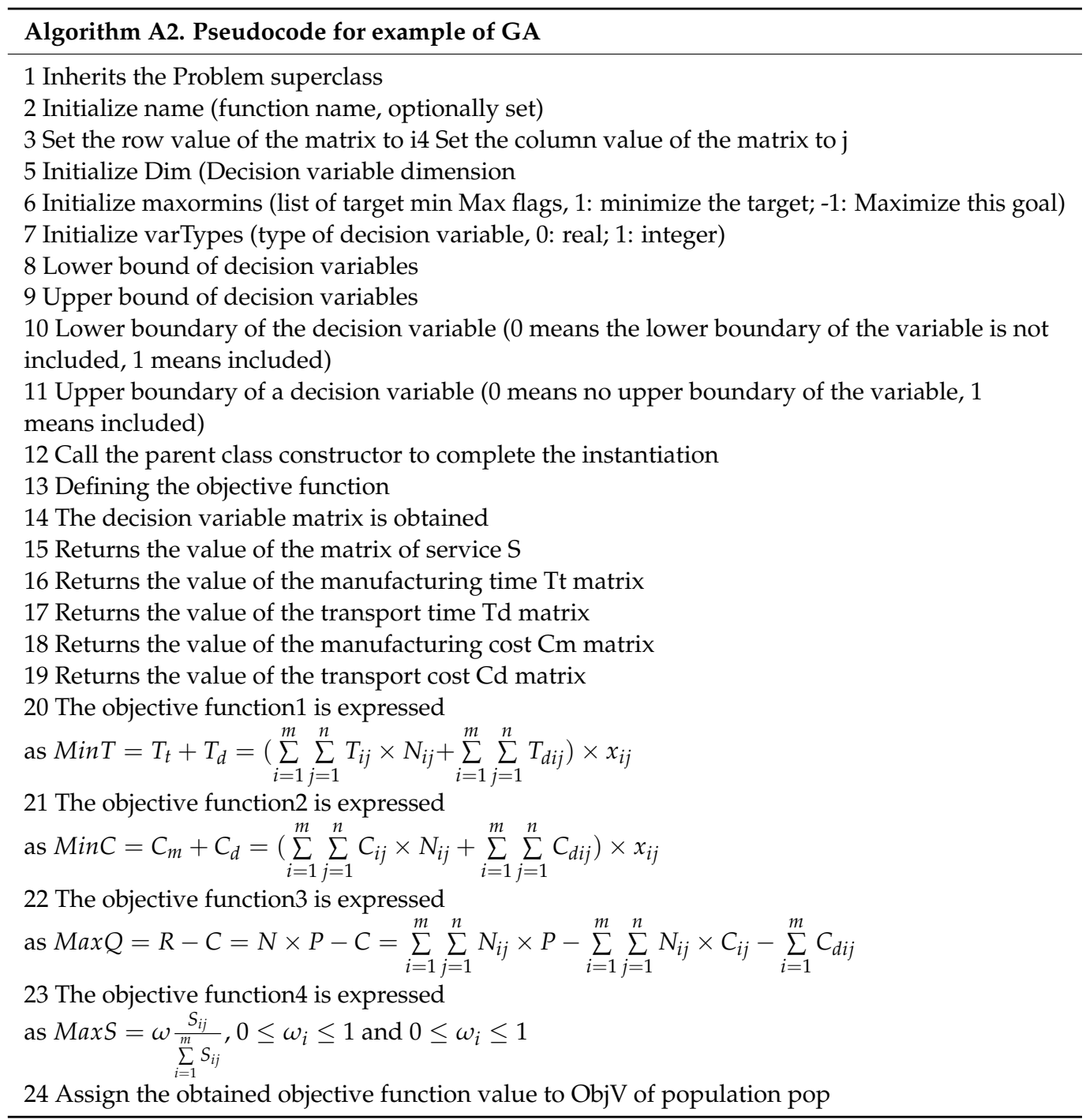

\section{References}

1. Lu, Y. Industry 4.0: A survey on technologies, applications and open research issues. J. Ind. Inf. Integr. 2017, 6, 1-10. [CrossRef]

2. Li, S.; Li, D.X.; Zhao, S. 5G Internet of Things: A survey. J. Ind. Inf. Integr. 2018, 10, 1-9. [CrossRef]

3. Li, L. China's manufacturing locus in 2025: With a comparison of "Made-in-China 2025" and "Industry 4.0". Technol. Soc. Chang. 2018, 135, 66-74. [CrossRef]

4. Cheng, Y.; Sun, F.Y.; Zhang, Y.P.; Tao, F. Task allocation in manufacturing: A review. J. Ind. Inf. Integr. 2019, 15, 207-218. [CrossRef]

5. Ebadifard, F.; Babamir, S.M. Federated Geo-Distributed Clouds: Optimizing Resource Allocation Based on Request Type Using Autonomous and Multi-objective Resource Sharing Model. Big Data Res. 2021, 24, 100188. [CrossRef]

6. Zhao, Y.; Guo, J.; Chen, X.; Hao, J.; Zheng, K. Coalition-based Task Assignment in Spatial Crowdsourcing. In Proceedings of the 2021 IEEE 37th International Conference on Data Engineering (ICDE), Chania, Greece, 1 April 2021; pp. $241-252$.

7. Liu, J.X.; Zhang, C. Research on member selection mechanism of virtual alliance and collaborative manufacturing among alliance enterprises under public service platform. Chin. J. Manag. Sci. 2020, 28, 126-135.

8. Zhou, Q.; Fang, M. Research on crowdsourcing task allocation algorithm based on Multi-agent. Intell. Comput. Appl. 2019, 9, 104-107.

9. Shahrabi, J.; Adibi, M.A.; Mahootchi, M. A reinforcement learning approach to parameter estimation in dynamic job shop scheduling. Comput. Ind. Eng. 2017, 110, 75-82. [CrossRef]

10. Erişgin Barak, M.Z.; Koyuncu, M. Fuzzy Order Acceptance and Scheduling on Identical Parallel Machines. Symmetry 2021, 13, 1236. [CrossRef]

11. Zhou, C.; Jiang, J.J.; Yin, M. Task allocation optimization for remote distributed collaborative development based on hybrid leapfrog algorithm. J. Ind. Eng. Eng. Manag. 2020, 34, 148-155.

12. Chaouch, I.; Driss, O.B.; Ghedira, K. A novel dynamic assignment rule for the distributed job shop scheduling problem using a hybrid ant-based algorithm. Appl. Intell. 2019, 49, 1903-1924. [CrossRef] 
13. Kurdi, M. An effective new island model genetic algorithm for job shop scheduling problem. Comput. Oper. Res. 2016, 67, 132-142. [CrossRef]

14. Nouri, H.E.; Driss, O.B.; Ghédira, K. Hybrid metaheuristics for scheduling of machines and transport robots in job shop environment. Appl. Intell. 2016, 45, 1-21. [CrossRef]

15. Salido, M.A.; Escamilla, J.; Giret, A.; Barber, F. A genetic algorithm for energy-efficiency in job-shop scheduling. Int. J. Adv. Manuf. Technol. 2016, 85, 1303-1314. [CrossRef]

16. Agárdi, A.; Nehéz, K.; Hornyák, O.; Koczy, L.T. A Hybrid Discrete Bacterial Memetic Algorithm with Simulated Annealing for Optimization of the Flow Shop Scheduling Problem. Symmetry 2021, 13, 1131. [CrossRef]

17. Zhou, P.; Xu, H.; Lu, F. Manufacturer's optimal output decision with bargaining power and co-production of by-products. Chin. J. Manag. Sci. 2020, 28, 156-163.

18. Wang, X.L.; Chai, X.D.; Zhang, C.; Zhao, X.F. Cross-enterprise collaborative production scheduling algorithm in cloud manufacturing environment. Comput. Integr. Manuf. Syst. 2019, 25, 412-420.

19. Meng, J.; Li, W.J.; Yu, G.R.; Wang, J.M.; Zhang, B.L. Utility maximization oriented dynamic resource allocation in data centers. Appl. Res. Comput. 2021, 38, 1728-1733, 1779.

20. Ren, L.; Ren, M.L. Collaborative assignment model of intelligent manufacturing tasks based on mixed task networks. Comput. Integr. Manuf. Syst. 2018, 24, 838-850.

21. Zheng, T.; Wang, Y.Y.; Xie, Z.H. Research on Multi-supplier collaborative Production Task allocation based on Big Data. Inn. Mong. Sci. Technol. Econ. 2019, 13, 44-47.

22. Wang, Q.; Tan, L. Task assignment algorithm for big data group computing based on user topic accurate perception. J. Comput. Appl. 2016, 36, 2777-2783.

23. Dickson, G.W. An analysis of vendor selection systems and decisions. J. Purch. 1966, 2, 5-17. [CrossRef]

24. Al-Shihabi, S.; Al-Durgam, M. Multi-objective optimization for the multi-mode finance-based project scheduling problem. Front. Eng. Manag. 2020, 7, 223-237. [CrossRef]

25. Kucuksayacigil, F.; Ulusoy, G. Hybrid genetic algorithm for bi-objective resource-constrained project scheduling. Front. Eng. Manag. 2020, 7, 426-446. [CrossRef] 